\title{
Causes of the Convergence Slowdown in the Countries of Central and Eastern Europe, 2008-2014
}

\author{
Wojciech Bieńkowski ${ }^{1}$, Wojciech Grabowski ${ }^{2, *}$ \\ ${ }^{1}$ Department of Economics and Management, Lazarski University, Poland \\ ${ }^{2}$ Department of Economics and Sociology, University of Lodz, Poland
}

Copyright $\bigcirc 2017$ by authors, all rights reserved. Authors agree that this article remains permanently open access under the terms of the Creative Commons Attribution License 4.0 International License

\begin{abstract}
In this paper we analyze the growth and real convergence process of the Central and Eastern European countries which joined the European Union in May 2004, namely Poland, the Czech Republic, Slovakia, Hungary, Lithuania, Latvia, Estonia and Slovenia (henceforth CEEC-8), vis-à-vis the European Union (EU) as a whole, individual EU members, and OECD countries (non-EU members). The analyses cover the period from 1995 to present. Results of testing beta-convergence indicate that in the period 2008-2014 the countries of the CEEC-8 group converged to Mediterranean countries but did not converge to rich countries of the European Union or non-EU OECD countries. We estimate parameters of the dynamic panel model to identify the causes of the convergence slowdown of CEECs. According to the results of the estimation, the low level of innovation in the countries under consideration was the main cause of both the slower TFP growth and the convergence slowdown.
\end{abstract}

Keywords Growth, Convergence, TFP Determinants, Dynamic Panel Model

\section{Introduction}

The main aim of this paper is to identify the causes of the significant growth and convergence slowdown in the 2008-2014 period in Central Eastern Europe Countries (CEEC-8) - Poland, the Czech Republic, Slovakia, Hungary, Lithuania, Latvia, Estonia, Slovenia - in relation to both the EU and the OECD countries (non-EU members), for which noticeable if not significant divergent tendencies can also be observed.

The growth and convergence slowdown and even the divergence process are relatively new phenomena for the CEECs, and it has come as a surprise to many economists and experts in the field because it has emerged after a slow but steady real convergence growth, as observed since these countries' successful systemic transformation following
1995, and especially due to their entry into the EU in 2004. Namely, due to these two extremely important factors (systemic transformation and the benefits derived from their access to the EU) the CEECs have moved up or converged from an average of approximately $40 \%$ of EU gross domestic product (GDP) per capita at purchasing power parity (PPP) in 1990 to 55\% in 2007 (Czasonis, Quinn, [8]).

Though the literature devoted to growth determinants in the countries of Central and Eastern Europe is very extensive, there is still a gap that should be bridged. Most analyses concentrate on the period of convergence, neglecting the fact that after the outbreak of the global financial crisis, a slowdown in convergence was observed. Using data showing the problem of innovativeness levels in the countries of Central and Eastern Europe, we point out the most important reasons for their convergence slowdown. Additionally, we contribute to the existing literature by showing the differences between countries in terms of both TFP determinants and TFP growth, and conduct counterfactual analyses which could provide useful hints for economic policies in the CEE countries.

The paper is divided into two parts. The first is devoted to the analysis of the growth and convergence process in the CEEC-8 group as observed since the beginning of the systemic transformation process in 1995 until 2014. It consists of both statistical analyses of the convergence process and the testing of hypotheses concerning beta-convergence, especially after the year 2007/2008 when the initial significant growth and convergence process broke down. The convergence process is monitored and analyzed by dividing the period 1995-2014 into three sub-periods: 1995-2003 (systemic transformation phase), 2004-2007 (advantages of the EU membership), and 2008-2014 (post-crisis period).

The second part of the paper is devoted to identifying and evaluating the causes of the CEECs' convergence slowdown after 2007/2008. For this purpose, we estimate the parameters of an econometric model. As it is widely recognized that success in real convergence depends on total factor productivity (TFP), we concentrate on the TFP 
determinants of the CEECs. We estimate the parameters of the dynamic panel model using the Blundell-Bond [5] systemic estimator in order to avoid the problem of endogeneity of some regressors.

\section{Literature Review}

The process of economic or real convergence has become a widely discussed issue, especially with reference to advances in the emerging economies, which have made considerable progress in catching up with the developed West and North in recent decades (see e.g. Kutan, Yigit [25]; Kutan, Yigit [26]; Matkowski, Próchniak [31]; Vojinovic, Oplotnik [39]; Gepper, Stephan [14]; Monastiriotis et al. [33]; Izumov, Vahaly [21]; Kushnirsky [24]).

The debate concerning middle-income economies - and the middle-income trap in particular - arose somewhat later, a decade or so ago, when some middle-income countries evidently stopped developing, at least in terms of real convergence towards developed ones. A number of valuable research studies were undertaken in relation to some Latin American and East Asian countries (Yusuf and Nabeshima [41]; Felipe [12]). Much of the research work has been done and/or supported by international financial institutions, for example the Asian Development Bank (Felipe [12]), the World Bank Development Research Group and the Inter-American Development Bank (Yusuf and Nabeshima [41]), as well as by the OECD Development Centre (e.g., Jankowska, Nagengast, and Perea [22]).

The middle income trap is a theorized economic development situation, when a country attains a certain income but gets stuck at that level. A country in the middle income trap will have lost competitive edge because wages are on a rising trend and work productivity increases slowly. Such country is unable to keep up with more developed economies in the high-value-added market. In order to avoid the middle income trap, strategies to introduce new processes should be identified and new markets should be found to maintain export growth.

The problem has become especially interesting, if not intriguing, in view of the great success of other ambitious countries - the Republic of Korea, Taiwan, Singapore, and Hong Kong - which tried to catch up and successfully converged, proving that real convergence is possible in the real world, not only in theory, provided the country embarks on an intelligently structured industrial policy, and remains consistent and persistent for a certain, rather long time (Lee [27], Lee et al. [28]).

Though all countries of the CEEC-8 group are classified as high-income countries (WESP [40]), convergence of the Central and Eastern European countries with the developed World slowed down after the global financial crisis took hold, suggesting a typical situation in which the above group of countries has entered the "middle-income economy trap". Indeed many economists from the countries under consideration warn about the middle income trap problem
(Radło [36]). As a result, an analysis of the convergence slowdown seems to be crucial and the identification of the causes may provide useful recommendations for economic policy.

Many studies have been devoted to analysing the determinants of the convergence of the CEECs. Baran [3] analysed determinants of the TFP growth of CEEC-4 countries (Poland, Czech Republic, Slovakia and Hungary) in the period 1995-2010. According to the results, TFP contributions to growth were very important in the CEEC-4 in 1995-2006. However, when the global crisis began, a significant slowdown in technological progress was recorded. According to the results obtained by Czasonis and Quinn [8], the countries of Central and Eastern Europe converged to the rich Western European countries very quickly before 2007. Kutan and Yigit [26] found convergence to Germany in industrial production for the new members of the European Union, in the 1993-2000 period. In contrast, Dogan and Saracoglu [10] did not find any evidence of convergence.

\section{Analysis of the Convergence of the CEEC-8}

To analyze the phenomenon of the convergence over the whole period 1995-2014 and in three sub-periods, we compare the growth rates of GDP per capita for the group of CEEC-8 with the growth rates of different groups of OCED member states. We divide the entire period into three sub-periods. The first sub-period encompasses 1995-2003, before the analysed countries joined the European Union. The second sub-period (2004-2007) covers the years after joining the European Union and before the global financial and economic crisis started.

At first glance, one can conclude that most of the CEEC-8 converged towards the EU-15 over the whole period 19952014. This progress is most visible in the Baltic countries, Poland and Slovakia, less impressive in the Czech Republic, Hungary and Slovenia. Another initial observation concerns the visible difference between the sub-periods in the CEECs' convergence process. During the first period, which we call the systemic transformation phase, CEECs moved from centrally planned economies based on public ownership to increasingly market-oriented economies based on private ownership, as well as shifting from foreign trade state monopolies toward open trade policies run by private companies and individuals. The process, as we know it, unleashed a considerable amount of previously frozen entrepreneurial energy, and started to reduce inefficiency in old publicly owned industrial structures, but this evolved in different ways in those countries because of the speed and/or nature of the economic policies adopted by them since 1990 . The results were sometimes unexpectedly negative, for example in terms of the efficiency of the newly formed private companies vis-à-vis old state enterprises, both in manufacturing and in agriculture (see Brada, and King [6]; Brada, King, and Ma [7]). 
Table 1. Rates of growth of real GDP per capita (in US\$) in Central and Eastern European countries and selected groups of countries over the whole period 1995-2014 and in sub-periods.

\begin{tabular}{|c|c|c|c|c|}
\hline Country/group of countries & 1995-2014 & $1995-2003$ & 2003-2008 & 2008-2014 \\
\hline Poland & $131 \%$ & $21 \%$ & $97 \%$ & $-3 \%^{1}$ \\
\hline Czech Republic & $121 \%$ & $43 \%$ & $86 \%$ & $-17 \%$ \\
\hline Hungary & $50 \%$ & $26 \%$ & $43 \%$ & $-17 \%$ \\
\hline Slovakia & $145 \%$ & $52 \%$ & $65 \%$ & $-2 \%$ \\
\hline Lithuania & $362 \%$ & $138 \%$ & $85 \%$ & $5 \%$ \\
\hline Latvia & $250 \%$ & $92 \%$ & $91 \%$ & $-4 \%$ \\
\hline Estonia & $232 \%$ & $82 \%$ & $75 \%$ & $4 \%$ \\
\hline Slovenia & $23 \%$ & $-2 \%$ & $48 \%$ & $-15 \%$ \\
\hline CEE & $111 \%$ & $25 \%$ & $83 \%$ & $-8 \%$ \\
\hline EU-15 & $29 \%$ & $16 \%$ & $22 \%$ & $-9 \%$ \\
\hline EU-Mediterranean (France, Spain, Portugal, Greece, Italy) & $26 \%$ & $17 \%$ & $25 \%$ & $-14 \%$ \\
\hline $\begin{array}{c}\text { EU-North (Germany, the Netherlands, Finland, Austria, } \\
\text { Denmark, Sweden, Luxembourg) }\end{array}$ & $35 \%$ & $17 \%$ & $22 \%$ & $-6 \%$ \\
\hline Non-EU OECD & $26 \%$ & $10 \%$ & $10 \%$ & $4 \%$ \\
\hline
\end{tabular}

Table 2. Testing beta-convergence. Estimates of the beta parameter. P-values for testing hypothesis that this parameter equals 0 are given in brackets.

\begin{tabular}{|c|c|c|c|c|}
\hline Group of countries & $\mathbf{1 9 9 5}-\mathbf{2 0 1 4}$ & $\mathbf{1 9 9 5}-\mathbf{2 0 0 3}$ & $\mathbf{2 0 0 3}-\mathbf{2 0 0 8}$ & $\mathbf{2 0 0 8}-\mathbf{2 0 1 4}$ \\
\hline \multirow{2}{*}{ EU-15 } & -0.015 & -0.004 & -0.048 & -0.007 \\
& $(0.30)$ & $(0.84)$ & $-0.01)$ & $-0.79)$ \\
\hline \multirow{2}{*}{ EU-Mediterranean } & -0.018 & -0.005 & -0.050 & $(0.07)$ \\
\hline \multirow{2}{*}{ EU-North } & $(0.29)$ & $(0.86)$ & $-0.04)$ & -0.004 \\
& -0.013 & -0.004 & $(0.02)$ & $(0.89)$ \\
\hline \multirow{2}{*}{ Non_EU OECD } & $(0.35)$ & $-0.83)$ & -0.069 & 0.006 \\
\end{tabular}

Table 3. Situation on the labor market and net migration in relation to population in the countries of the CEEC-8 group

\begin{tabular}{|c|c|c|c|c|c|c|}
\hline \multirow{2}{*}{ Country } & \multicolumn{2}{|c|}{ Unemployment rate } & \multicolumn{2}{|c|}{ Net migration in relation to population } & \multicolumn{2}{|c|}{ Population ages 15-64 (\% of total) } \\
\hline & 2007 & 2012 & 2007 & 2012 & 2007 & 2012 \\
\hline Czech Republic & 5.3 & 7 & 0.024 & 0.003 & 71.1 & 69.1 \\
\hline Estonia & 4.7 & 10.1 & -0.011 & -0.009 & 67.9 & 66.5 \\
\hline Hungary & 7.4 & 10.9 & 0.010 & 0.003 & 68.7 & 68.3 \\
\hline Latvia & 6.0 & 14.9 & -0.039 & -0.036 & 67.9 & 66.8 \\
\hline Lithuania & 4.3 & 13.2 & -0.044 & -0.057 & 67.4 & 67.4 \\
\hline Poland & 9.6 & 10.1 & 0.000 & -0.002 & 71.1 & 71.0 \\
\hline Slovakia & 11.0 & 13.9 & 0.002 & 0.001 & 72.1 & 72.1 \\
\hline Slovenia & 4.8 & 8.8 & 0.025 & 0.002 & 70.2 & 68.6 \\
\hline
\end{tabular}

1 Although Poland was the only country in the EU to avoid recession, the depreciation of its national currency against the US dollar resulted in a decrease in the real value of GDP per capita measured in US\$. 
The second period in the CEECs' convergence process is symbolically marked by 2004 , when the analyzed countries became EU members and so we define this phase the EU yield period. This is a symbolic distinction because the effects/benefits related to the CEECs' membership started to take place even earlier (ca. 2000), when the pre-accession agreements indicated clearly that the countries had already embarked on the institutional convergence process with the EU (acquis communautaire), establishing a safe ground for international investors that resulted, ultimately, in both a significant FDI inflow into the CEEC-8 and the acceleration of growth.

The other obvious benefits of either expected or real EU membership included free access to EU markets for CEEC-8 exporters (e.g., Poland attained duty free access to EU markets when its accession agreement had been signed and approved by all EU member countries in 1994), EU assistance programs (which could be up to $4 \%$ of CEECs' GDP), and the free movement of people. This latter benefit included systematically implemented legal work permits for the outflow of labor, easing the - in some countries dramatic - unemployment problem, as well as resulting in substantial money transfers remitted by emigrants to their mother countries. As an example, Poland has been receiving US\$5-7 billion annually from such remittances since EU membership.

The positive effects of the above factors, in addition to the benefits coming from the increasingly mature systemic transformation process (mostly thanks to progressive privatization processes, open trade benefits, and on-going institutional adjustments), resulted in the significant acceleration of GDP growth in these countries. As can be seen from the Table 1, CEECs experienced an unprecedented rapid GDP growth in the period 2004-2007, leading them to be considered the group of "fast growing countries," that is, countries with a GDP per capita average annual growth rate of $3.5 \%$ for seven or more years.

The problem is that the happy era of growth in the period 2000-2007, and in the 2004-2007 sub-period in particular, ended dramatically following 2007, bringing most of the CEECs' convergence almost to a stop. This came as a surprise to economists, politicians, and experts alike (see EBRD, 2014). Over time, however, the negative tendency of growth in the CEECs started to be better recognized and understood when data showed that unemployment in the CEECs had started to grow (see Table 3). As a result of the slowdown in growth and investment, which brought a rise in unemployment, yet another plague started to be a problem, namely CEECs' emigration began to grow rapidly. This trend has eased unemployment on the one hand, but it has a dangerous weak point, namely the age composition of the labor outflow consisting primarily of young and middle-aged educated people (see Table 3). The development of all these negative factors has resulted in a visible slowdown in the convergence of CEECs vis-à-vis the total EU. The CEECs' declining GDP growth rates since
2008 have contributed to the convergence slowdown.

Other factor making the CEECs' convergence vis-à-vis the total EU easier to achieve has been the EU Mediterranean countries' negative and/or relatively slow growth for most of the period 2008-2014. This phenomenon is in contrast to the relatively positive growth rates of most of the rest of the EU-15, which we can call the EU-North, comprising the Scandinavian countries, Austria, Germany, Belgium, the Netherlands, the UK, Ireland, and Luxemburg. As we can observe, the Mediterranean countries as a group, having had negative and/or very slow GDP growth rates over that period, are the only EU area against which the CEECs can claim a real convergence process (Table 1). As a result of the simultaneous development of the two opposite tendencies, namely relatively faster EU-North growth and negative and/or very slow growth in the Mediterranean countries (see Table 1), and given the visible slowdown in growth in the CEECs in that period, the CEECs' convergence toward the total EU and EU-15 has been very low, with some minor positive differences with respect to Poland, Slovakia, and Estonia. By examining Non-EU OECD countries, we note that the total EU position has worsened vis-à-vis both OECD Anglo-Saxon countries overseas and most small and medium-sized OECD countries, such as Switzerland, Chile, Israel, and Turkey. Indeed GDP per capita differences have been growing in favor of OECD non-EU members, and the EU surplus position has diminished vis-à-vis Chile, Switzerland, Turkey, and Israel.

We can also see that the OECD non-EU members have been growing at faster pace than most of the countries in Central and Eastern Europe. Similar negative conclusions may be found comparing CEECs' GDP growth rates with both OECD Anglo-Saxon countries and Switzerland, Israel, and Turkey, to mention but a few of the fast moving OECD non-EU members. As a result, we find that a divergence process has been well under way, rather than the convergence experienced by the CEECs' before 2008. This may suggest that the CEECs have reached a kind of plateau in their developmental path as measured by the real convergence process and the progress. If the convergence process cannot be revived, we must admit that the CEECs have become stuck in the middle-income trap, as did many Latin American and some East Asian countries years before.

Though all countries of the CEEC- 8 group are classified as high-income countries (WESP [40]), convergence of the Central and Eastern European countries with the developed World slowed down after the global financial crisis took hold, suggesting a typical situation in which the above group of countries has entered the "middle-income economy trap". Indeed many economists from the countries under consideration warn about the middle income trap problem (Radło [36]).

Analysis of GDP growth rates for the period 2015-2016 indicates that in these years negative tendency did not 
improve. Average growth rates for Estonia and Lithuania was below the EU-average. In the case of Latvia, Slovenia and Poland the GDP growth rate was a bit better and only in the case of Romania this indicator was satisfactory. However some high-income countries recorded very high growth rates in the analyzed period (e.g. Ireland, Iceland, Malta, Luxembourg), which means that the problem of divergence of some countries of the Central and Eastern Europe is still valid.

\section{Econometric Analysis of the Determinants of the Total Factor Productivity (TFP) Growth Rate}

According to the Solow growth accounting, the growth rate of output is decomposed into (Solow [36]): changes in the quantity of the physical capital, changes in the amount of labour, unexplained factor reflecting technological progress and called the "Solow residual" or "Total factor productivity".

TFP accounts for a significant proportion of the differences in income across countries. Since obtaining a measure of TFP growth on an economy-wide level is a difficult task, two main alternatives are used: growth accounting and frontier analysis. According to the growth accounting approach, TFP growth is identified as the value of the residual of the production function after accounting for the contribution of the inputs' changes to output growth. Therefore changes in the Total-Factor Productivity reflect both changes in the efficiency of production and technological progress, while the non-parametric (production-frontier) method enables this decomposition (see: Baran [3]). In the empirical research, we used the growth accounting approach to calculate the Total-Factor Productivity for all countries of the CEEC-8 group for the period 1996-2014.

Before the econometric model is specified, economic theories devoted to the determinants of TFP should be mentioned. The following groups of variables are distinguished (see: Barro, Sala-i-Martin [4]; Isaksson [20]; Herrendorf, Valentinyi [18]; Danquah, Moral-Benito, Ouattara, [9]): variables associated with the creation, transmission, and absorption of knowledge, variables associated with factor supply and efficient allocation, variables associated with institutions, integration, and invariants, variables associated with competition, social dimensions, and the environment.

An important factor for TFP growth is an effective innovation system. Through this means, research and development (R\&D) is fostered and results in new products, processes, and knowledge. Therefore, the value of investment in R\&D (or its stock) is very often used as an explanatory variable in models explaining TFP (see e.g. Gullec and Van Pottelsberghe de la Potterie [17]). As knowledge is created by a small number of countries and most countries need state-of-the-art technology, they must acquire it from elsewhere. Foreign direct investment (FDI) is very often perceived as a key channel for the transfer of advanced technology from highly developed to developing countries. Moreover, it is believed that FDI generates positive externalities in the form of spillovers of knowledge to the domestic economy due to linkages with local clients and suppliers, learning from foreign firms, and employee training programs. Therefore, FDI is perceived as a factor that has a positive impact on productivity (see, e.g. Isaksson [20]).

Trade is also considered a carrier of knowledge and some authors argue that thanks to imports, advanced foreign technology is introduced into domestic production, which in turn positively affects TFP. On the other hand, technology adoption from abroad and the creation of good domestic technology require human capital. An improvement results in an increase in TFP. Therefore, trade openness is very often used as an explanatory variable in models explaining TFP (see, e.g. Danquah et al. [9]).

Good education and training help a society increase its ability to acquire and use relevant knowledge. Level of education, which is commonly used as a measure of human capital, has an important effect on TFP as it plays a very important role in shaping an economy's capacity to carry out technological innovation and adopt new technology (see, e.g. Romer [37]). The level of health in a society influences growth in TFP directly through household wealth, and indirectly through labor productivity, investments, savings, and demography. Healthy workers are more productive and lower mortality rates result in larger savings (Danquah et al. [9]). Infrastructure plays an important role in expanding productive capacity by increasing resources and enhancing private capital productivity. Therefore, the stock of infrastructure is very often used as a factor influencing the level of productivity.

The strength of state institutions has an important impact on TFP in a country. In economies with weak institutions, the availability of funds for investment and capital accumulation is poorer than in strong economies. As a result, variables associated with the level of development of state institutions should also be used to explain TFP. In economies with developed financial systems, investment opportunities can be seized, the allocation of resources is closer to optimum, and specialization is promoted. Moreover, financial constraints may prevent poor countries from obtaining the advantage of technology transfer. The role of financial development is to help firms or industries to take advantage of growth opportunities by allocating resources to the most productive use. Therefore a variable associated with the level of development of the financial system should also be used as an explanatory variable in regression analysis explaining TFP. The percentage of state-owned enterprises most likely also plays an important role in explaining TFP. State-owned enterprises are inefficient compared to private ones (see: Isaksson [20]). 
The privatization of enterprises therefore results in increased competition, as it reduces management slack. The relative inefficiency of state-owned enterprises might be due to political pressures, and the lack of separation between control and ownership. Another explanation for the lower efficiency of state-owned enterprises is the fact that they seldom try to maximize profits and have greater incentives to adopt anti-competitive behavior. All in all, variables associated with the state of privatization should also be considered in models explaining growth in TFP.

Some works devoted to the determinants of TFP highlight the role of the social dimension, which denotes income, wealth distribution, and the wealth level in an economy. It seems that the greater the difference between owners of capital and workers, the lower the motivation of workers and their productivity (e.g. Isaksson [20]). Therefore, measures associated with income inequality may also be used in regression analyses of TFP growth.

On the basis of data availability and the significance ${ }^{2}$ of variables in explaining technological change, we finally estimate the parameters of the following model:

$$
T F P_{-} G R_{i t}=\mathbf{z}_{i t} \boldsymbol{\alpha}+\varepsilon_{i t}
$$

where $\mathbf{z}_{i t}$ consists of explanatory variables as defined in Table 4. Before we began estimation, panel unit root tests were conducted. The results of testing of the order of integration of time series are presented in Table 5. They indicate that the variables used in the specification (1) are stationary. In the case of non-stationary variables, we used differences. Therefore, we didn't have any problems with spurious regression. We estimated the parameters of the model (1) using the Blundell-Bond systemic estimator (Blundell, Bond [5]). Use of this method results from the fact that we have the problem of endogeneity of certain variables in the equation (1). Frankel and Romer [13] show that trade is endogenous, while Dollar and Kraay [11] show that finance is also endogenous. The Blundell-Bond estimator solves the problem of endogeneity (Baltagi, [2]). Moreover, results of the Monte Carlo simulations indicate that this estimator is the most efficient among dynamic panel data estimators. A similar methodology in the same context was applied by, among others, Khan [23] for the African continent.

Due to availability of data, we can estimate the parameters of the dynamic panel model using yearly data for the period 1996-2014. Our sample covers Central and Eastern European countries that joined the EU in 2004, i.e., Poland, the Czech Republic, Hungary, Slovakia, Lithuania, Latvia, Estonia and Slovenia.

Table 5 presents the results of the estimation of the parameters of the dynamic panel model using Blundell and Bond's [5] systemic estimator, as well as the results of validity testing for over-identifying restrictions and the presence of autocorrelation of order 2 .
The positive and significant estimate of the parameter for the variable TFP_GR $\mathrm{it}_{\mathrm{it}-1}$ means that the growth rate of TFP is positively correlated with its lag. The positive estimate of the parameter for the variable SAV_GR $\mathrm{Gi}_{\mathrm{it}}$ means that in the group of CEEC-8 increasing the ratio of savings to GDP had a greater chance of an increase in productivity in the years 2008-2013. A larger level of savings results in the accumulation of capital, which is necessary for buying new technology enabling the attainment of higher levels of productivity. The ratio of domestic credit to private sector to GDP turned out to have a negative impact on the rate of growth of TFP. This means that the "too much finance" hypothesis may be valid for the countries of the Central and Eastern Europe (Próchniak, Wasiak [35]; Grabowski, Maciejczyk-Bujnowicz [15], [16]).

It can be noted that the ratio of the ICT goods trade to total trade also had a positive impact on the rate of TFP growth in the years 2011-2014. The value of quantity informs on the level of development of the ICT sector in an economy; the better the development of this sector, the higher the rate of TFP growth. The positive and significant estimate of the parameter for the variable FDI means that FDI generated positive externalities in the form of spillovers of knowledge to the domestic economy due to linkages with local clients and suppliers, learning from foreign firms, and employee training programs. However the estimate of the parameter for the variable TO is negative, which is a very strange result. This may be due to the low level of advancement of the majority of goods traded between the Central and Eastern European countries and their trade partners. Indeed, the percentage of high-technology exports in total exports was only about $10 \%$ (average) in the group of countries analyzed in 2013 and was much lower than in highly-developed countries (Singapore 47\%, Switzerland $27 \%$, the Netherlands $20 \%$, Norway $19 \%$ ). The ratio of the ICT goods trade to total trade is very low in the group of countries analyzed, which means that less advanced goods dominate in trade. As a result, an increase in the ratio of trade to GDP does not lead to higher productivity levels. The ratio of bank capital to assets turns out to have a negative and significant impact on the level of productivity in year 2009. This provides information on the role of stability in the banking sector in influencing investors' perceptions of the level of risk associated with a specific country. A higher level of banking assets indicates a higher level of the safety of investments in a specific country to investors, leading to greater investment and a higher productivity level. Moreover, a higher level of stability in the banking sector results in higher levels of credit provision to firms, which is necessary for buying new technology.

2 We drop insignificant variables 
Table 4. Definitions of variables used in the model.

\begin{tabular}{|c|c|c|c|}
\hline Variable & Definition & Source of data & Units \\
\hline$T F P \_G R$ & Yearly rate of growth TFP & $\begin{array}{l}\text { Calculated on the basis of } \\
\text { Solow residuals }\end{array}$ & Percentage change \\
\hline TERT_STAFF_WOMEN & $\begin{array}{l}\text { Percent of female in academic staff } \\
\text { in tertiary education }\end{array}$ & World Bank, WDIs & Percentage points \\
\hline UNEMP & Unemployment rate (\% of total labor force) & World Bank, WDIs & Percentage points \\
\hline COMP_EXPORT & $\begin{array}{c}\text { Percentage of computer, communications } \\
\text { and other services export } \\
\text { in commercial service exports. } \\
\end{array}$ & World Bank, WDIs & Percentage points \\
\hline DOM_CREDIT & Domestic credit to private sector ( $\%$ of GDP) & World Bank, WDIs & Percentage points \\
\hline$I N T \_P A Y$ & Interest payments ( $\%$ of expense) & World Bank, WDIs & Percentage points \\
\hline SOCIAL_CONTR & Social contributions ( $\%$ of revenue) & World Bank, WDIs & Percentage points \\
\hline UNEMP_TERT & $\begin{array}{l}\text { Unemployment with tertiary education ( } \% \text { of } \\
\text { total unemployment) }\end{array}$ & World Bank, WDIs & Percentage points \\
\hline$E Q \_I N D E X$ & S\&P Global Equity Index (annual \% change) & World Bank, WDIs & Percentage points \\
\hline EXPEND & Gross national expenditure (\% of GDP) & World Bank, WDIs & Percentage points \\
\hline FDI & Ratio of FDI to GDP & World Bank, WDIs & Ratio*100 \\
\hline TO_GR & Yearly change in trade openness & World Bank, WDIs & Percentage points \\
\hline$S A V \_G R$ & $\begin{array}{l}\text { Yearly change in the ratio of gross savings to } \\
\text { GDP }\end{array}$ & World Bank, WDIs & Percentage points \\
\hline$I C T \_T R A D E \_G R$ & $\begin{array}{l}\text { Yearly change in the percentage of ICT trade } \\
\text { (in total trade) }\end{array}$ & World Bank, WDIs & Percentage points \\
\hline$B C T A R$ & Bank capital to assets ratio & World Bank, WDIs & Ratio*100 \\
\hline$A V A \_G R$ & Yearly change in agricultural value added & World Bank, WDIs & Percentage points \\
\hline$E D U C \_E X P \_G R$ & $\begin{array}{l}\text { Yearly change in ratio of educational } \\
\text { expenditure to GDP }\end{array}$ & World Bank, WDIs & Percentage points \\
\hline$R D \_R E S \_G R$ & $\begin{array}{l}\text { Yearly percentage change in number of } \\
\text { researchers in R\&D }\end{array}$ & World Bank, WDIs & Percentage points \\
\hline TRMARK_GR & $\begin{array}{l}\text { Yearly percentage change in trademark } \\
\text { applications }\end{array}$ & World Bank, WDIs & Percentage points \\
\hline
\end{tabular}


Table 5. Results of testing order of integration for variables used in the model using panel unit root tests. Values of statistics and p-values (in brackets) are given.

\begin{tabular}{|c|c|c|c|c|c|c|c|c|}
\hline \multirow{2}{*}{ Variable } & \multicolumn{2}{|c|}{ Levin, Lin, Chu [29] } & \multicolumn{2}{|c|}{ Im, Pesaran, Shin [19] } & \multicolumn{2}{|c|}{$\begin{array}{c}\text { ADF-Fisher (Maddala, } \\
\text { Wu [30]) }\end{array}$} & \multicolumn{2}{|c|}{$\begin{array}{l}\text { PP-Fisher (Maddala, Wu } \\
{[30] \text { ) }}\end{array}$} \\
\hline & Level & $\begin{array}{c}\text { First } \\
\text { difference }\end{array}$ & Level & $\begin{array}{c}\text { First } \\
\text { difference }\end{array}$ & Level & $\begin{array}{c}\text { First } \\
\text { difference }\end{array}$ & Level & $\begin{array}{c}\text { First } \\
\text { difference }\end{array}$ \\
\hline$T F P \_G R$ & $\begin{array}{l}-5.17 \\
(0.00) \\
\end{array}$ & - & $\begin{array}{l}-3.45 \\
(0.00) \\
\end{array}$ & - & $\begin{array}{l}64.48 \\
(0.00) \\
\end{array}$ & - & $\begin{array}{l}75.53 \\
(0.00) \\
\end{array}$ & - \\
\hline$F D I$ & $\begin{array}{l}-4.87 \\
(0.00) \\
\end{array}$ & - & $\begin{array}{l}-2.89 \\
(0.00) \\
\end{array}$ & - & $\begin{array}{l}48.41 \\
(0.00) \\
\end{array}$ & - & $\begin{array}{l}51.30 \\
(0.00)\end{array}$ & - \\
\hline TO & $\begin{array}{l}-0.99 \\
(0.16)\end{array}$ & $-8.16(0.00)$ & $\begin{array}{c}2.05 \\
(0.98)\end{array}$ & $-6.16(0.00)$ & $\begin{array}{c}8.62 \\
(0.99)\end{array}$ & $\begin{array}{l}114.08 \\
(0.00)\end{array}$ & $\begin{array}{c}8.64 \\
(0.99)\end{array}$ & $\begin{array}{l}137.36 \\
(0.00)\end{array}$ \\
\hline$U N E M P$ & $\begin{array}{l}-4.12 \\
(0.00)\end{array}$ & - & $\begin{array}{l}-0.14 \\
(0.44)\end{array}$ & $-2.55(0.00)$ & $\begin{array}{l}44.98 \\
(0.00)\end{array}$ & - & $\begin{array}{l}47.25 \\
(0.00)\end{array}$ & - \\
\hline UNEMP_TERT & $\begin{array}{l}-5.89 \\
(0.00) \\
\end{array}$ & - & $\begin{array}{l}-6.04 \\
(0.00) \\
\end{array}$ & - & $\begin{array}{l}89.65 \\
(0.00) \\
\end{array}$ & - & $\begin{array}{l}190.73 \\
(0.00) \\
\end{array}$ & - \\
\hline$R D \_R E S \_G R$ & $\begin{array}{l}-3.42 \\
(0.00)\end{array}$ & - & $\begin{array}{l}-4.53 \\
(0.00) \\
\end{array}$ & - & $\begin{array}{l}38.72 \\
(0.00)\end{array}$ & - & $\begin{array}{l}82.88 \\
(0.00)\end{array}$ & - \\
\hline BCTAR & $\begin{array}{c}0.98 \\
(0.84) \\
\end{array}$ & $-7.74(0.00)$ & $\begin{array}{l}-1.10 \\
(0.32)\end{array}$ & $-4.63(0.00)$ & $\begin{array}{l}14.09 \\
(0.72)\end{array}$ & $43.49(0.00)$ & $\begin{array}{l}16.61 \\
(0.55)\end{array}$ & $\begin{array}{l}193.37 \\
(0.00)\end{array}$ \\
\hline$I N T \_P A Y$ & $\begin{array}{l}-2.53 \\
(0.01)\end{array}$ & - & $\begin{array}{l}-0.00 \\
(0.50)\end{array}$ & $-3.97(0.00)$ & $\begin{array}{l}28.97 \\
(0.02)\end{array}$ & - & $\begin{array}{l}26.24 \\
(0.05)\end{array}$ & - \\
\hline$T E R T \_S T A F F \_W O M E N$ & $\begin{array}{l}-2.63 \\
(0.00)\end{array}$ & - & $\begin{array}{l}-5.11 \\
(0.00)\end{array}$ & - & $\begin{array}{l}44.20 \\
(0.00)\end{array}$ & - & $\begin{array}{l}104.74 \\
(0.00)\end{array}$ & - \\
\hline COMP_EXPORT & $\begin{array}{l}-2.75 \\
(0.00) \\
\end{array}$ & - & $\begin{array}{c}0.36 \\
(0.64) \\
\end{array}$ & $-5.84(0.00)$ & $\begin{array}{l}26.61 \\
(0.04)\end{array}$ & - & $\begin{array}{l}147.26 \\
(0.00)\end{array}$ & - \\
\hline$S A V_{-} G R$ & $\begin{array}{l}-4.86 \\
(0.00) \\
\end{array}$ & - & $\begin{array}{l}-5.03 \\
(0.00) \\
\end{array}$ & - & $\begin{array}{l}51.92 \\
(0.00) \\
\end{array}$ & - & $\begin{array}{l}117.03 \\
(0.00)\end{array}$ & - \\
\hline EXPEND & $\begin{array}{l}-0.35 \\
(0.36) \\
\end{array}$ & $-8.72(0.00)$ & $\begin{array}{c}2.09 \\
(0.98) \\
\end{array}$ & $-5.05(0.00)$ & $\begin{array}{c}6.67 \\
(0.98) \\
\end{array}$ & $\begin{array}{c}111.82 \\
(0.00) \\
\end{array}$ & $\begin{array}{c}5.59 \\
(0.99) \\
\end{array}$ & $92.23(0.00)$ \\
\hline$E Q \_I N D E X$ & $\begin{array}{l}-3.69 \\
(0.00)\end{array}$ & - & $\begin{array}{l}-4.02 \\
(0.00)\end{array}$ & - & $\begin{array}{l}32.56 \\
(0.00)\end{array}$ & - & $\begin{array}{l}61.30 \\
(0.00)\end{array}$ & - \\
\hline$A V A \_G R$ & $\begin{array}{c}-6.41 \\
(0.00) \\
\end{array}$ & - & $\begin{array}{c}-5.28 \\
(0.00) \\
\end{array}$ & - & $\begin{array}{r}89.89 \\
(0.00) \\
\end{array}$ & - & $\begin{array}{c}157.29 \\
(0.00) \\
\end{array}$ & - \\
\hline TRMARK_GR & $\begin{array}{c}-3.86 \\
(0.00)\end{array}$ & - & $\begin{array}{c}-5.00 \\
(0.00)\end{array}$ & - & $\begin{array}{c}74.42 \\
(0.00)\end{array}$ & - & $\begin{array}{c}148.86 \\
(0.00)\end{array}$ & - \\
\hline$I C T \_T R A D E \_G R$ & $\begin{array}{c}-3.75 \\
(0.00)\end{array}$ & - & $\begin{array}{c}-5.68 \\
(0.00)\end{array}$ & - & $\begin{array}{l}89.91 \\
(0.00)\end{array}$ & - & $\begin{array}{l}188.16 \\
(0.00)\end{array}$ & - \\
\hline DOM_CREDIT & $\begin{array}{c}-2.42 \\
(0.01)\end{array}$ & - & $\begin{array}{c}0.24 \\
(0.60)\end{array}$ & $-2.95(0.00)$ & $\begin{array}{c}15.83 \\
(0.46)\end{array}$ & $52.79(0.00)$ & $\begin{array}{c}9.02 \\
(0.91)\end{array}$ & $60.78(0.00)$ \\
\hline SOCIAL_CONTR & $\begin{array}{c}-3.03 \\
(0.00)\end{array}$ & - & $\begin{array}{c}-1.67 \\
(0.05)\end{array}$ & - & $\begin{array}{c}12.53 \\
(0.70) \\
\end{array}$ & $65.82(0.00)$ & $\begin{array}{l}31.29 \\
(0.01)\end{array}$ & - \\
\hline$E D U_{-} E X P_{-} G R$ & $\begin{array}{c}-7.03 \\
(0.00)\end{array}$ & - & $\begin{array}{c}-5.22 \\
(0.00)\end{array}$ & - & $\begin{array}{l}101.26 \\
(0.00)\end{array}$ & - & $\begin{array}{l}141.73 \\
(0.00)\end{array}$ & - \\
\hline
\end{tabular}

Source: Own calculations 
Table 6. Estimation results for parameters of the dynamic panel model using the systemic Blundell-Bond [5] estimator.

\begin{tabular}{|c|c|c|c|}
\hline Variable & Estimate & Standard error & p-value \\
\hline Cons & 0.305 & 0.034 & 0.000 \\
\hline$T F P \_G R_{i t-1}$ & 0.195 & 0.041 & 0.000 \\
\hline TERT_STAFF_WOMEN & 0.0048 & 0.0022 & 0.029 \\
\hline UNEMP & -0.0081 & 0.0025 & 0.001 \\
\hline COMP_EXPORT & 0.0018 & 0.0009 & 0.047 \\
\hline$\triangle D O M \_C R E D I T$ & -0.0005 & 0.0003 & 0.078 \\
\hline$I N T \_P A Y$ & -0.0149 & 0.0063 & 0.020 \\
\hline SOCIAL_CONTR & -0.0014 & 0.0008 & 0.076 \\
\hline UNEMP_TERT & -0.0051 & 0.0025 & 0.038 \\
\hline$E Q_{-} I N D E X_{i t-1}$ & 0.0002 & 0.0001 & 0.024 \\
\hline$\triangle E X P E N D$ & -0.0106 & 0.0030 & 0.000 \\
\hline$F D I$ & 0.0012 & 0.0005 & 0.011 \\
\hline$\triangle T O$ & -0.0023 & 0.0003 & 0.000 \\
\hline$S A V_{-} G R$ & 0.0161 & 0.0041 & 0.000 \\
\hline$I C T \_T R A D E \_G R$ & 0.0203 & 0.0068 & 0.002 \\
\hline$B C T A R$ & -0.0171 & 0.0032 & 0.000 \\
\hline$A V A \_G R$ & -0.1930 & 0.0710 & 0.003 \\
\hline RD_RES_GR & 0.2910 & 0.1170 & 0.013 \\
\hline TRMARK_GR & 0.1980 & 0.0440 & 0.000 \\
\hline$E D U C_{-} E X P_{-} G R_{i t-2}$ & 0.0054 & 0.0013 & 0.000 \\
\hline Testing the presence of the autocorrelation of order 2 & \multicolumn{3}{|c|}{$\begin{array}{l}\text { Statistic }=0.18 \\
\text { p-value }=0.85\end{array}$} \\
\hline Sargan test of over-identifying restrictions & \multicolumn{3}{|c|}{$\begin{array}{c}\text { Statistic }=126.37 \\
\text { p-value }=0.20\end{array}$} \\
\hline
\end{tabular}

Two more variables associated with the level of innovativeness of the economy turn out to be statistically significant, exerting a positive impact on the level of productivity in the group of countries analyzed. A) An upward change in the number of scientists in R\&D positively affects the change in TFP. Therefore, governments should spend more money on research and concentrate on branches in which R\&D is important. Instead of spending money on less skilled jobs and university faculties not associated with R\&D, more money should be spent on faculties in which $\mathrm{R} \& \mathrm{D}$ is essential. B) A percentage change in trademark applications has a significant and positive impact on the change in TFP. An increase in trademark applications is associated with an increase in the range of products supplied. The provision of products new to the market requires the use of advanced technology, which ultimately leads to an increase in the level of productivity.

The positive and significant estimate of the parameter for the variable EDUC EXP $\mathrm{GR}_{\mathrm{it}-2}$ means that the growth in expenditure on education positively affects productivity growth with a lag of two years. This result is in line with expectations, as an increase in educational expenditure leads to an improvement in human capital, which should lead to the higher productivity of workers. In addition, an increase in expenditure on tertiary education associated with engineering and science faculties should lead to the development of new technologies and an increase in productivity. A change in the proportion of value added in agriculture to total output has a negative impact on the change in TFP. At the beginning of the transformation process, the share of employment in agriculture and the share of added value in agriculture were at relatively high levels in the Central and Eastern European countries. The decrease in the significance of agriculture started as a result of the process of transformation from centrally planned to market economies. Simultaneously, a decrease in the proportion of value added in agriculture to total output resulted in an increase of the significance of services and manufacturing. This might have led to the development of more innovative products in services and manufacturing, and to the increase in the change in TFP, which is in line with the estimate.

A variable representing the percentage of women employed as academic staff in tertiary education turned out to be significant, and had a positive impact on TFP growth. This result means that the governments of Central and Eastern Europe should be open to stimulating the academic careers of women and provide conditions that enable maintaining an academic career while also bringing up children. A higher percentage of well-educated women indicates a higher level of gender equality in a given country. 
This means that all citizens contribute to the innovativeness of their country.

Two variables associated with the situation on the labour market turned out to be statistically significant: the unemployment rate and percentage of unemployed with a tertiary education both have a significant negative impact on TFP growth. This means that the governments of the CEE countries should take special care of their labour markets, and introduce programmes that enable a reduction of the unemployment rate among new university graduates. If new graduates have problems finding appropriate jobs they emigrate, and so the percentage of well-educated citizens in the labour force decreases. Estimates of the parameters for the variables INTEREST_PAYMENT and EXPEND show that governments should look at their public finances, in order to reduce interest payments, and that the percentage of expenses in GDP should be reasonable. If a government does not look after its public finances, investors' fears about debt sustainability are reflected in a higher level of treasury bond yields. Investors are then less prone to investing in their own countries, which leads to slower technological progress. A positive estimate of the parameter for the variable EQ_INDEX is in line with expectations. Countries recording an increase of equity prices are wealthier, and their citizens can invest more money in innovative technology.

A variable representing situation in the banking sector turned out to be statistically significant as well. The higher is the bank capital to assets ratio, the slower is TFP growth. This result is in line with Mero and Piroska [32]. These authors have found that banking and economic nationalism in the countries of the Central and Eastern Europe prevented economic development and better integration to $\mathrm{EU}$ structures.

It should also be noted that some variables turned out to be nonsignificant, and these variables were not included in the final specification. This especially concerns variables associated with female labor participation and the proportion of women in wage employment in non-agricultural sectors. Because of cultural aspects, women in Central and Eastern European countries quite frequently participate in the labor force (in some countries, female labor participation is greater than that of male labor participation). Therefore, changes in female labor participation do not have a significant impact on changes in TFP. Variables demonstrating inequality were not included in the final specification due to poor data availability. The results of testing for autocorrelation of order 2 confirm that including further lags of the dependent variable is not justified. The results of the Sargan test confirm that over-identifying restrictions are valid and the specification of the dynamic panel model is correct.

To identify the main reasons for convergence slowdown and weak change in Total-Factor Productivity, the performance of the main variable, as well as variables reflecting the level of innovativeness will be analysed. Data for countries from the CEEC-8 group will be compared with data for highly-developed countries. Table 7 presents the average annual changes of Total-Factor Productivity and the performance of innovative variables in the period 2011-2014 in the countries under consideration, as well as in selected highly-developed countries. Results from table 7 indicate that the level of innovativeness in the countries of Central and Eastern Europe is much lower than in Germany and Israel. The number of R\&D researchers and the percentage of ICT service exports are very low in comparison with highly-developed countries. Moreover, the trend in ICT exports and trademark applications is not optimistic for most of the CEEC-8 group, with the most pessimistic trend observed in Hungary. However, positive cases in this group can be identified as well. A relatively high level of innovativeness is recorded for the Baltic states (except Estonia), and Slovakia. Analysis of the results from tables 1 and 7 indicates that the countries of Central and Eastern Europe should make efforts to increase their level of innovativeness if they want to catch up. In the countries with the strongest divergence tendencies (the Czech Republic, Hungary, Slovenia), the level of innovativeness is low. Countries that recorded increases or only slight decreases of GDP per capita in the crisis period (Slovakia, Lithuania, Latvia) are outperforming the other countries of the analysed region in terms of innovativeness.

To evaluate what the situation would have been if the Central and Eastern European countries had made stronger efforts in terms of innovativeness, we compared (using exact numbers) the empirical level of the TFP growth rate with the theoretical level in the period 2012-2014, assuming the values of innovation variables (ICT_TRADE_GR, RD_RES_GR, TRMARK_GR, COMP_EXPORT) to have been at the level of two highly-developed countries (Germany and Israel) in all countries from 2008. Table 8 presents the empirical and theoretical paths. In Table 8, we also note that the rate of TFP growth would have been significantly higher had the Central and Eastern European countries concentrated more on ICT trade and tried to increase the ratio of $\mathrm{R} \& \mathrm{D}$ researchers in the population. All in all, appropriate measures associated with increasing innovativeness and improving human capital should be implemented, to put a stop to the very dangerous tendency toward divergence noted in the years 2008-2014. Because of differences in the innovative effort of the countries under consideration, there are differences in the "TFP growth gap" across countries. The Czech Republic, Hungary and Slovenia are able to increase their Total-Factor Productivity significantly when they make the effort to increase their innovativeness, which - especially in these countries - is very weak. 
Table 7. Average yearly TFP changes and performance of innovative variables in the countries of the CEEC-8 group and selected highly-developed countries.

\begin{tabular}{|c|c|c|c|c|}
\hline Country & $\begin{array}{c}\text { Average yearly TFP } \\
\text { change in the period } \\
\mathbf{2 0 1 2 - 2 0 1 4}\end{array}$ & $\begin{array}{c}\text { Change in the trademark } \\
\text { applications in the period } \\
\mathbf{2 0 1 2 - 2 0 1 4} \text { (\%) }\end{array}$ & $\begin{array}{c}\text { Change in the ICT service export } \\
\text { (\% of service export) in the period } \\
\mathbf{2 0 1 2 - 2 0 1 4} \text { (in percentage points) }\end{array}$ & $\begin{array}{c}\text { Researchers in R\&D (per } \\
\text { million people). Average value } \\
\text { from the period 2012-2014 }\end{array}$ \\
\hline $\begin{array}{c}\text { Czech } \\
\text { Republic }\end{array}$ & 0.012 & -10 & +0.94 & 3273 \\
\hline Estonia & 0.003 & -2 & +0.14 & 3361 \\
\hline Hungary & -0.026 & +10.1 & -1.02 & 2522 \\
\hline Lithuania & 0.047 & -2.8 & +1.44 & 2836 \\
\hline Latvia & 0.029 & -12.5 & +2.87 & 1867 \\
\hline Poland & 0.020 & -3.6 & +0.17 & 1873 \\
\hline Slovakia & 0.032 & -2.4 & +2.14 & 2752 \\
\hline Slovenia & 0.011 & -23.1 & +0.65 & 4224 \\
\hline Germany & 0.022 & +9.4 & +0.87 & 4386 \\
\hline Israel & 0.042 & +4 & +2.77 & 8255 \\
\hline
\end{tabular}

Table 8. Empirical and theoretical (assuming the values of innovation variables to have been at the level of Germany and Israel) values of the TFP change

\begin{tabular}{|c|c|c|c|}
\hline Country & $\begin{array}{c}\text { Average yearly, } \\
\text { empirical TFP change } \\
\text { in the period } \\
\text { 2012-2014 }\end{array}$ & $\begin{array}{c}\text { Average yearly, theoretical TFP change in the } \\
\text { period 2012-2014 (assuming the values of } \\
\text { innovation variables to have been } \\
\text { at the level of Germany) }\end{array}$ & $\begin{array}{c}\text { Average yearly, theoretical TFP change in the } \\
\text { period 2012-2014 (assuming the values of } \\
\text { innovation variables to have been } \\
\text { at the level of Israel) }\end{array}$ \\
\hline $\begin{array}{c}\text { Czech } \\
\text { Republic }\end{array}$ & 0.012 & 0.043 & 0.047 \\
\hline Estonia & 0.003 & 0.036 & 0.037 \\
\hline Hungary & -0.026 & 0.034 & 0.038 \\
\hline Lithuania & 0.047 & 0.051 & 0.050 \\
\hline Latvia & 0.029 & 0.046 & 0.049 \\
\hline Poland & 0.020 & 0.044 & 0.046 \\
\hline Slovakia & 0.032 & 0.047 & 0.047 \\
\hline Slovenia & 0.011 & 0.035 & 0.037 \\
\hline
\end{tabular}

\section{Conclusions}

Though all countries of the CEEC-8 group are classified as high-income countries (WESP [40]), convergence of the Central and Eastern European countries with the developed World slowed down after the global financial crisis took hold, suggesting a typical situation in which the above group of countries has entered the "middle-income economy trap". Therefore many economists from the countries under consideration warn about the middle income trap problem and identification of the causes of convergence slowdown seems to be important. The results of the analysis of the CEECs' performance in terms of both GDP per capita growth and the convergence process, as well as the results of the estimation of the parameters of the TFP growth, show that the convergence of the Central and Eastern European countries with the world economy slowed down after outbreak of the global financial crisis in 2008, suggesting a typical situation in which the above group of countries has fallen into the "middle-income economy trap".

In the first part of our analyses, based primarily on a in-depth statistical investigation, we find that although the countries under consideration had relatively high GDP growth rates after 2000, and especially after their access to EU, soon after, in the period of the global financial crisis 2007-2008, their GDP slowdown was very significant. What is more, the slow convergence of the CEECs toward the total EU in the period 2008-2013 can be attributed predominantly to the very deep recession in part of the euro area, mostly in the Mediterranean countries, rather than to their good economic performance in absolute terms. Indeed, measuring the CEECs' performance vis-à-vis EU-North, namely such countries as Germany or Sweden, during the period 2008-2014, a divergent process can even be observed. Similar negative results are observed after 2008, especially when comparing the CEECs' growth results with those of other world economies, such as OECD non-EU member countries, for example the Anglo-Saxon countries, such as the USA, Canada, Australia, and New Zealand, and other OECD member states, such as Switzerland, Chile, Israel, and Turkey, not to mention the East Asian tigers such as the Republic of Korea and Taiwan, which show two or three times higher GDP growth rates two or three times higher than those of the CEECs over the 2008-2014 period.

To deepen our statistical analyses and observations, and knowing that most of the GDP growth rates in the countries 
analyzed have predominantly been TFP-driven, we have implemented econometric modeling to estimate the significance of TFP factors in the development of CEECs' GDP and convergence. In other words, we propose the estimation of parameters of the chosen dynamic panel model and the use of the Arellano-Bond [1] and BlundellBond [5] estimators. Using this dynamic panel model and the estimators, we come to the conclusion that the CEECs' slowdown in convergence results from relatively low rates of growth in TFP in Central and Eastern Europe. This may be due to low investments generally and the low innovativeness of these countries (especially Poland). The numbers of patents and $R \& D$ expenditure are relatively low in the case of Central and Eastern European countries. This leads to slower growth in TFP and a slowdown in convergence. These countries' competiveness has primarily been driven by low labor costs, which is not a sufficient condition for maintaining the long-term ability to compete. Although the human capital index increased very rapidly in these countries, the coefficient may give misleading information as higher education in CEECs was not adjusted to market requirements, resulting in a large percentage of people with university education but not the appropriate capabilities. To advance and avoid being stuck in the middle-income trap, these countries should spend less money on consumption and more money on investment and R\&D. Policy makers in Central and Eastern European countries should concentrate more on adjusting the profiles of higher education to the new challenges of the modern world.

Moreover convergence slowdown in the countries under consideration was due to bad economic policy choices of CEECs governments to combat the crisis (Myant, Drahokupil, [34]). Banking and economic nationalism prevented economic development and better integration to EU structures (Mero, Piroska [32]).

The analyses showed differences within the CEEC-8 group. The strongest divergence tendencies were observed for the Czech Republic, Slovenia and Hungary, where increases in innovation were very slow. On the other hand, Lithuania, Latvia and Slovakia outperformed other countries in terms of innovativeness and converged faster than the highly-developed OECD countries. Analysis of the results across countries could contribute something to discussion of the choice of exchange rate mechanisms in the countries of Central and Eastern Europe. In general, the Baltic states and Slovakia - members of the EMU - perform better than the Czech Republic, Hungary and Poland, which have their own currencies. Large fluctuations in the EUR/PLN, EUR/HUF and EUR/CZK exchange rates might have resulted in a high level of uncertainty associated with doing business in Poland, Hungary and the Czech Republic. Therefore, enterprises in these countries made less innovative effort and used price levels as their main competitive tool. In the short-run, a positive GDP growth rate (in local currency) was recorded in the case of Poland at the beginning of the global financial crisis. In the long-run, however the countries that entered the EMU and increased their innovative effort (Latvia, Lithuania, Slovakia) outperformed Poland.

\section{Acknowledgements}

The authors gratefully acknowledge the contribution of the anonymous reviewers whose comments have enabled a significant improvement in the earlier version of the paper. The paper was written with the financial support of National Science Centre, Poland, under grant No. 2015/19/D/HS4/03354.

\section{REFERENCES}

[1] M. Arellano, S. Bond. Some tests of specification for panel data: Monte Carlo evidence and an application to employment equations, Review of Economic Studies, Vol.58, 277-297, 1991.

[2] B.H. Baltagi. Econometric analysis of panel data, Wiley, London, 2008.

[3] K.A. Baran. The Determinants of Economic Growth in Hungary, Poland, Slovakia and the Czech Republic During the Years 1995-2010, Equilibrium. Quarterly Journal of Economics and Economic Policy, Vol.8, 7-26, 2013

[4] R.J. Barro, X. Sala-i-Martin. Economic growth, Mc Graw-Hill Inc.

[5] R. Blundell, S. Bond. Initial conditions and moment restrictions in dynamic panel data models, Journal of Econometrics, Vol. 87, 115-143, 1998.

[6] J.C. Brada, A.E. King. Is Private Farming More Efficient than Socialized Agriculture?, Economica, Vol. 60, 41-56.

[7] J.C. Brada, A.E. King, C.Y. Ma. Industrial Economics of the Transition: Determinants of Enterprise Efficiency in Czechoslovakia and Hungary, Oxford Economic Papers, Vol. 49, 104-127, 1997.

[8] M. Czasonis, M.A. Quinn. Income convergence in Europe: catching up or falling behind? Acta Oeconomica, Vol. 62 183-204, 2012.

[9] M. Danquah, E. Moral-Benito, B. Ouattara. TFP growth and its determinants: a model averaging approach. Empirical Economics, Vol. 47, 227-251, 2014.

[10] N. Dogan N, B. Saracoglu. Income Convergence of European Union and Candidate Countries: Are they All the Same? International Research Journal of Finance and Economics, Vol. 12, 160-164, 2007.

[11] D. Dollar, A. Kraay. Growth is good for the poor. Journal of Economic Growth, Vol. 7, 195-225, 2002.

[12] J. Felipe. Tracking the Middle-Income Trap: What is It, Who is in It, and Why? Part 2. Asian Development Bank, https://www.adb.org/publications/tracking-middle-income-tr ap-what-it-who-it-and-why-part-2, 2012. 
[13] J.A. Frankel, D.H. Romer. Does Trade Cause Growth? American Economic Review, Vol. 89, 379-399, 1999.

[14] K. Gepper, A. Stephan. Regional Disparities in the European Union: Convergence and Agglomeration. Papers in Regional Science, Vol. 87, 193-217, 2006.

[15] W. Grabowski, I. Maciejczyk-Bujnowicz. Optimizing the level of bank credit to promote economic growth. Implications for Poland, Studia Naukowe Uniwersytetu Ekonomicznego w Katowicach, Vol. 269, 99-111, 2016.

[16] W. Grabowski, I. Maciejczyk-Bujnowicz. Verification of the hypothesis, Too much finance" in the polish economy, Central European Review of Economics and Finance, Vol. 12, 41-52, 2016.

[17] D. Gullec, B. Van Pottelsberghe de la Potterie. R\&D and Productivity Growth: Panel Data Analysis of 16 OECD Countries, OECD Economic Studies, Vol. 33, 103-126, 2001.

[18] B. Herrendorf, A. Valentinyi. Which Sectors Make Poor Countries So Unproductive? Journal of the European Economic Association, Vol. 10, 323-341, 2012.

[19] K.S. Im, M.H. Pesaran, Y. Shin. Testing for unit roots in heterogeneous panels. Journal of Econometrics, Vol. 115, 53-74, 2003.

[20] A. Isaksson. Determinants of total factor productivity: a literature review. Research and Statistics Branch Staff Working Paper.

http://www.unido.org//fileadmin/user_media/Publications/R esearch and statistics/Branch publications/Research and P olicy/Files/Working_Papers/2007/WP022007\%20-\%20Deter minants $\% 20$ of $\% 20$ total $\% 20$ factor $\% 20$ productivity.pdf, 2007.

[21] A. Izumov, J. Vahaly. Old Capital vs. New Investment in Post-Soviet Economies: Conceptual Issues and Estimates. Comparative Economic Studies, Vol. 50, 63-83, 2003.

[22] A. Jankowska, A.J. Nagengast, J.R. Perea. The Middle-Income Trap: Comparing Asian and Latin American Experiences. OECD Development Centre, Policy Insights 96, 2012, doi: $10.1787 / 20772599$.

[23] F.A. Khan. Economic convergence in the African continent: Closing the gap, South African Journal of Economics, Vol. 82, 354-370, 2014.

[24] F. Kushnirsky. A Modification of the Production Function for Transition Economies Reflecting the Role of Institutional Factors. Comparative Economic Studies, Vol. 42, 1-30, 2001.

[25] A.M. Kutan, T.M. Yigit. Nominal and Real Stochastic Convergence of Transition Economies. Journal of Comparative Economics, Vol. 32, 23-36, 2004.

[26] A.M. Kutan, T.M. Yigit. Nominal and Real Stochastic Convergence: Are the New EU Members Ready to Join the Euro Zone? Journal of Comparative Economics, Vol. 33, 387-400, 2005.
[27] K. Lee. Schumpeterian Analysis of Economic Catch-up Knowledge, Path-Creation, and the Middle-Income Trap, Cambridge University Press, Cambridge, 2013.

[28] K. Lee, B-Y Kim, Y-Y Park, E. Sanidas. Big Business and Economic Growth: Identifying a Binding Constraint for for Growth with Country Panel Analysis, Journal of Comparative Economics Vol.41, 561-582, 2013.

[29] A. Levin, C.F. Lin, J.C. Chu. Unit root tests in panel data: Asymptotic and finite sample properties, Journal of Econometrics, Vol. 108, 1-24, 2002.

[30] G.S. Maddala, S. Wu. A comparative study of unit root tests with panel data and a simple new test, Oxford Bulletin of Economics and Statistics, Vol. 61, 631-652, 1999.

[31] Z. Matkowski, M. Próchniak. Economic Convergence between the CEE- 8 and the European Union. Eastern European Economics 45: 59-76

[32] K. Mero, D. Piroska. Banking Union and Banking Nationalism - Explaining Opt-Out Choices of Hungary, Poland and the Czech Republic, International Business School Working Paper, 1/2016.

[33] V. Monastiriotis, D. Kallioras, G. Petrakos. The regional impact of European Union association agreements: an event-analysis approach to the case of Central and Eastern Europe. Regional Studies, doi: 10.1080/00343404.2016.1198472, 2016.

[34] M. Myant, J. Drahokupil. International integration, varieties of capitaslism, and resilience to crisis in transition economies, Europe-Asia Studies, Vol. 64, 1-33, 2012.

[35] M. Próchniak, K. Wasiak. The impact of the financial system on economic growth in the context of the global crisis: empirical evidence for the EU and OECD countries. Empirica. Doi: 10.1007/s10663-016-9323-9.

[36] M.J. Radło. Strzeżmy się tej pułapki, http://www.forbes.pl/czy-polska-jest-w-pulapce-sredniego-d ochodu-,artykuly,194379,1,1.html, 2015.

[37] P.M. Romer. Endogenous Technical Change, Journal of Political Economy, Vol. 98, 71-102, 1990.

[38] R.M. Solow. Technological Change and the Aggregate Production Function, Review of Economics and Statistics, Vol. 39, 312-320, 1957.

[39] B. Vojinovic, Z.J. Oplotnik Real Convergence of GDP per Capita in the New EU Member States. Transformations in Business and Economics, Vol. 7, 89-103, 2008.

[40] WESP. World Economic Situation and Prospects, http://ww w.un.org/en/development/desa/policy/wesp/wesp_current/20 14wesp_country_classification.pdf, 2014

[41] S. Yusuf, K. Nabeshima. Can Malaysia Escape the Middle-Income Trap? A Strategy for Penang. The World Bank Development Research Group, Policy Research Working Paper 4971, 2009. 